\title{
Information Seeking Behaviour Student in Foreign Language Education Student in Indonesia University of Education
}

\section{Perilaku Pencarian Informasi Mahasiswa Pendidikan Bahasa Asing di Universitas Pendidikan Indonesia}

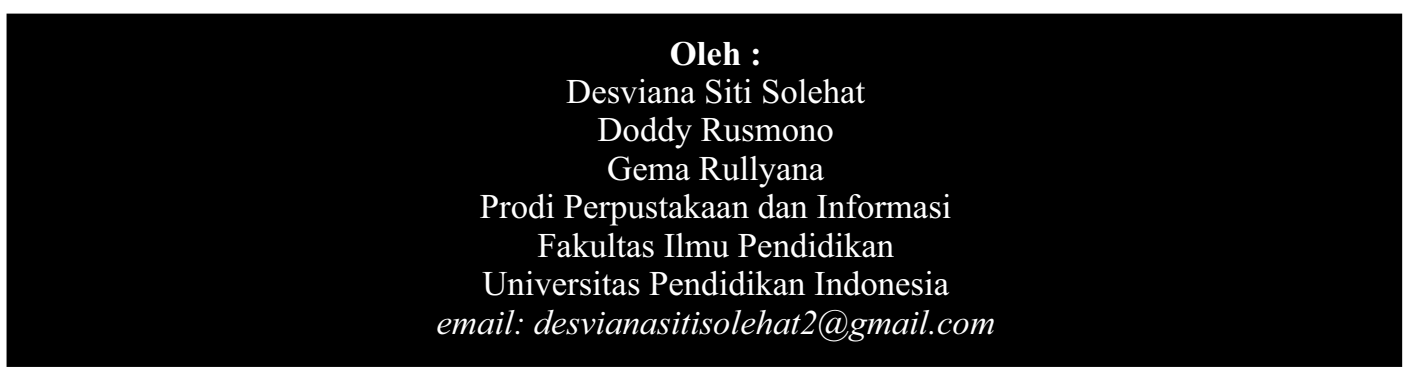

Abstrak. Sulitnya mencari literatur bahasa asing di perpustakaan menjadi masalah bagi mahasiswa departemen bahasa asing dalam memenuhi kebutuhan informasi akademiknya. Tujuan dilakukannya penelitian ini secara umum adalah untuk mengetahui perilaku pencarian informasi mahasiswa Departemen Pendidikan Bahasa Asing Universitas Pendidikan Indonesia dalam memenuhi kebutuhan informasinya. Tujuan khusus penelitian ini adalah (1) untuk mengetahui informasi apa yang diperlukan mahasiswa Departemen Pendidikan Bahsa Asing (DPBA), (2) untuk mengetahui asal sumber informasi mahasiswa DPBA, (3) untuk mengetahui perilaku pencarian informasi mahasiswa DPBA, dan (4) untuk mengetahui hambatan yang timbul dalam melakukan pencarian informasi. Penelitian ini merupakan penelitian kualitatif deskriptif dengan model studi kasus. Penentuan subjek penelitian dilakukan dengan teknik purposive sampling. Informan dalam penelitian ini adalah 12 mahasiswa dari enam departemen bahasa asing yang berbeda yakni Departemen Pendidikan Bahasa Arab, Departemen Pendidikan Bahasa Jepang, Departemen Pendidikan Bahasa Jerman, Departemen Pendidikan Bahasa Perancis, Departemen Pendidikan Bahasa Korea, dan Departemen Pendidikan Bahasa Inggris. Teknik pengumpulan data menggunakan wawancara dan studi dokumentasi. Berdasarkan hasil wawancara dan analisis data yang telah dilakukan peneliti, maka hasil penelitian ini menunjukkan bahwa mahasiswa membutuhkan informasi berupa buku penunjang seperti buku teks, modul, video, dan rekaman, literatur mengenai kebudayaan, kesusastraan, dan tata bahasa. Sumber informasi yang digunakan mahasiswa adalah ruang baca, buku, internet, dan sumber manusia. Kemudian, perilaku pencarian informasi mahasiswa adalah dengan starting, chaining, browsing, differentiating, extracting, verifying, dan ending, serta hambatan internal dan eksternal yang dialami mahasiswa.

Kata kunci: Kebutuhan Informasi, Perilaku Pencarian Informasi, Sumber Informasi 
Abstract. Based on the result of observation, the students of foreign language departements find the dificulty for finding foreign languages literature. It becomes a main problem for them to fulfill their information needs, especially for supporting their academic needs. Generally, this research aims to determine the information seeking behavior of foreign language departement' students. Meanwhile, the specific purposes of this research are 1) determining types of information those are needed by the students of Department Foreign Language Education (DFLE), 2) finding the sources of information those are needed by them, 3) knowing the information seeking behavior of DFLE students, and 4) determining the obstacles when seking information. This research is done by using descriptive qualitative and case sudy model.. Purposive sampling is used for selecting informants. There are twelve informants from six different foreign language departements, those are departement of arabic language education, departement of japanese language education, departemen of germanic language education, departement of french language education, departement of korean language education, and departement of english language education. Interview and document study are chosen as techniques of collecting data. The result shows that text books, module, video and record, literature about cultures and grammar are kind of library collection those are needed by them. Reading room, books, and internet, and human explanation are the sources they used to get information. The information seeking behavior of students are starting, chaining, browsing, differentiating, extracting, verifying, and ending. Barrier of seeking information come from internal and external.

\section{Keywords : Information Needs, Information Seeking Behavior, Information Sources}




\section{PENDAHULUAN}

Kebutuhan informasi tidak dapat terpenuhi dengan sendirinya tanpa ada usaha untuk mencari informasi tersebut. Aktivitas pencarian informasi inilah yang disebut perilaku pencarian informasi. Perilaku manusia dipengaruhi oleh kebutuhan akan suatu hal. Fenomena ini akan membuat seseorang berperilaku berbeda antara satu sama lainnya ketika dihadapkan pada suatu masalah. Kebutuhan merupakan alasan dan dorongan seseorang yang menyebabkan ia harus melakukan sesuatu untuk memenuhinya.

Perilaku pencarian informasi adalah perilaku seseorang yang selalu terus bergerak berdasarkan lintas ruang dan waktu, mencari informasi untuk menjawab segala tantangan yang dihadapi, menentukan fakta, memecahkan masalah menjawab pertanyaan, dan memahami suatu masalah. Saat ini banyak permasalahan yang berkaitan dengan informasi sendiri, seperti sulitnya mendapatkan informasi yang relevan dengan kebutuhan, pemilihan sumber informasi yang dapat dipercaya, meluapnya informasi, dan sebagainya menyebabkan seseorang perlu selektif dalam menggunakan informasi yang didapatkannya.

Seseorang harus memiliki kemampuan dalam menyaring segala informasi yang masuk, sehingga informasi yang didapatkan tidak keliru dan dapat dipergunakan untuk aktivitas yang dilakukan.

Di kalangan sivitas akademis, khususnya mahasiswa, informasi yang didapatkan tidak hanya sekedar harus terpenuhi namun juga harus berkualitas dan dapat dipertanggungjawabkan kebenarannya. Mahasiswa dituntut memiliki kemandirian dalam pemenuhan kebutuhan informasinya, utamanya terkait aktivitas perkuliahan. Keberadaan perpustakaan sendiri sangat mendukung dalam pemenuhan kebutuhan informasi pemustaka. Keberadaan perpustakaan merupakan hal yang penting mengingat proses pendidikan di perguruan tinggi tidak terlepas dari kegiatan penelitian dan pengembangan, inovasi, serta rekayasa ilmu pengetahuan.

Perpustakaan Universitas Pendidikan Indonesia merupakan perpustakaan yang berada di tingkat perguruan tinggi. Sebagai perpustakaan perguruan tinggi, perpustakaan ini bisa dikategorikan baik dari segi kelengkapan koleksi dan pelayanannya. Namun, keterbatasan perpustakaan ini adalah kurangnya literatur bahasa asing dan literatur penunjang bagi mahasiswa bahasa asing. Hal ini, sedikit banyak dirasakan oleh mahasiswa Departemen Pendidikan Bahasa Asing sehingga banyak dari mereka tidak menjadikan Perpustakaan Universitas Pendidikan Indonesia sebagai sumber utama dalam pemenuhan kebutuhan informasi. 
Selain itu, ada beberapa hambatan lain yang dirasakan mahasiswa, yakni keterbatasan pengaksesan literatur online sampai pencarian informasi dari luar negeri. Oleh karena itu, sumber informasi merupakan suatu hal yang penting dalam memenuhi kebutuhan informasi mahasiswa, sehingga dapat mendukung proses pembelajaran mahasiswa maupun kebutuhan individu mereka.

Perilaku pencarian informasi mahasiswa didorong oleh kebutuhan akademiknya. Mahasiswa Departemen Pendidikan Bahasa Asing sebagai salah satu pengguna informasi juga tidak luput dari kebutuhan informasi. Kebutuhan akan literatur informasi ini didasarkan untuk mendukung segala aktivitas akademis yang dijalankannya baik dalam penyelesaian tugas perkuliahan maupun menyelesaikan tugas akhirnya.

Keterlibatan mahasiswa dalam pembelajaran merupakan hal yang saat ini diterapkan pada lingkungan Perguruan Tinggi. Mahasiswa perlu literatur yang mendukung pembelajaran, baik dari segi materi perkuliahan maupun pembelajaran secara mandiri. Pringgoadisuryo (dalam Darmono, 2001, hlm.21), menyatakan bahwa "kesiapan unit informasi untuk memberikan dukungan terhadap kebutuhan informasi masyarakat di lingkungan sekitar pencari informasi, berpengaruh terhadap perilaku pencarian informasi”.

Sejalan dengan pendapat tersebut menegaskan bahwa pencari informasi yang dalam hal ini adalah mahasiswa akan datang ke tempat yang akan memberikan pemenuhan akan kebutuhan informasi akademiknya. Jika, kebutuhan informasi mahasiswa dapat didukung oleh keberadaan perpustakaan dalam lingkungan lembaganya, maka pemenuhan akan kebutuhan akademik akan lebih mudah didapatkan. Sebaliknya, jika perpustakaan dirasa tidak dapat memenuhi kebutuhan informasinya maka seseorang akan mendatangi sumber informasi lain.

Di tingkat yang lebih mikro, sebenarnya hampir setiap departemen telah memiliki ruang baca masing-masing untuk menunjang kebutuhan mahasiswanya. Setelah peneliti melakukan kunjungan pada beberapa ruang baca Departemen Pendidikan Bahasa Asing yakni Ruang Baca Departemen Pendidikan Bahasa Perancis dan Ruang Baca Departemen Pendidikan Bahasa Jepang, serta bertanya kepada mahasiswa, peneliti mendapati bahwa ruang baca Departemen ini sudah dikelola dengan baik walaupun ada departemen yang ruang bacanya bersatu dengan ruang dosen.

Kemudian ada juga departemen yang sudah tidak memiliki ruang baca sama sekali karena alasan tertentu. Ini merupakan hal yang menarik untuk diteliti mengingat pentingnya keberadaan ruang baca ini untuk memenuhi 
kebutuhan mahasiswa. Hal ini berpengaruh kepada pola perilaku mahasiswa itu sendiri dalam mencari informasi. Oleh karena itu, peneliti tertarik untuk melakukan penelitian mengenai perilaku pencarian informasi mahasiswa bahasa asing, mencari tahu sumber informasi yang digunakan mahasiswa, dan hambatan yang selama ini dirasakan mahasiswa dalam mencari informasi. Kemudian peneliti juga ingin mencari tahu apakah ruang baca yang dimiliki departemen menjadi salah satu sumber informasi yang mempunyai efek besar dalam menunjang kebutuhan informasi mahasiswa.

Peneliti memilih mahasiswa Departemen Pendidikan Bahasa Asing sebagai subjek penelitian karena melihat kenyataan bahwa sulitnya mencari literatur yang sesuai dengan departemen tersebut. Kesulitan ini salah satunya disebabkan oleh cara dan pengetahuan yang dimiliki setiap orang berbeda. Selain itu Mahasiswa Departemen Pendidikan Bahasa Asing yang berada di Universitas Pendidikan Indonesia merasakan dan beranggapan bahwa hanya sedikit dari koleksi Perpustakaan Universitas Pendidikan Indonesia yang menunjang kebutuhan dan proses pembelajaran mereka.

Oleh karena itu, mahasiswa Departemen Pendidikan Bahasa Asing harus mencari cara lain dalam hal pemenuhan kebutuhan informasi mereka selain datang ke perpustakaan UPI seperti memanfaatkan ruang baca departemen, mencari di jurnal online, laporan penelitian, mencari informasi kepada orang lain, ahli bidang tertentu dan sebagainya. Mahasiswa juga harus berhadapan dengan keterbatasan bahasa yang mereka miliki, juga kesulitan mendapatkan sumber informasi yang mendukung aktivitas perkuliahan.

Peneliti menggunakan model pencarian informasi Ellis (dalam Wilson, 1999, hlm. 254-255), dalam mendukung penelitian. Hal ini dikarenakan model ini cukup umum untuk menjelaskan proses pencarian informasi dalam berbagai situasi. Dari model tersebut akan diketahui apakah situasi pencarian informasi mahasiswa Departemen Pendidikan Bahasa Asing sesuai dengan tahapan atau tidak.

\section{Kebutuhan Informasi}

Kebutuhan akan informasi berawal dari pemikiran dalam diri seseorang dan menuntut jawaban atas ketidaktahuan yang dimilikinya. Menurut Khulthau dalam Suwanto (1997, hlm.19), "kebutuhan informasi muncul karena adanya gap (kesenjangan informasi) antara informasi yang dimiliki oleh seseorang dan informasi yang dibutuhkannya". Dengan kata lain, seseorang dikatakan membutuhkan informasi saat ia mulai menyadari adanya jarak antara pengetahuan yang dimiliki 
dengan informasi yang harus dipenuhinya.

Kesenjangan informasi yang dimiliki seseorang kemudian menjadi kebutuhan yang harus dipenuhi. Dalam memenuhi kebutuhan informasinya, seseorang harus mengetahui dengan jelas informasi yang dibutuhkannya dan format yang dibutuhkannya untuk mempermudah proses pencarian informasi yang akan dilakukan kedepannya.

\section{Sumber Informasi}

Informasi bisa didapatkan dengan berbagai cara dan sumber dalam bentuk yang berbeda. Sumber informasi sendiri adalah sarana atau tempat penyimpanan informasi. Informasi dapat diperoleh dari sumber dokumen dan non dokumen. Untuk sumber informasi dokumen dapat ditemukan dalam bentuk buku, majalah, jurnal, hasil-hasil penelitian seperti skripsi, tesis, disertasi, dan sebagainya. Untuk sumber informasi non dokumen dapat diperoleh dari manusia seperti dosen, teman, pakar atau ahli, pustakawan, spesialis informasi, dan sebagainya. Menurut Setiarso (dalam Rozinah, 2012, hlm.8-9), sumber informasi terdapat pada:

a. Manusia

Sumber informasi yang berupa nondokumen bisa diperoleh dari manusia seperti teman, pustakawan, pakar (ahli), atau spesialis informasi.
Manusia sebagai sumber informasi dapat dihubungi baik secara lisan maupun tertulis. Yang paling lazim digunakan untuk kontak langsung dengan sumber ini adalah pertemuan dalam bentuk ceramah, panel diskusi, konferensi, lokakarya, seminar, dan lain-lain.

b. Organisasi

Badan atau lembaga penelitian baik milik pemerintah maupun swasta yang bergerak dalam bidang sejenis merupakan sumber informasi penting termasuk industri dan himpunan profesi. Dalam hal ini, mereka memiliki kemampuan karena memiliki fasilitas berupa tenaga peneliti, peralatan atau laboratorium, perpustakaan, dan jasa informasi yang tersedia.

c. Literatur

Literatur atau publikasi dalam bentuk terbaca maupun mikro merupakan sumber informasi yang cukup majemuk. Literatur dapat dikelompokkan menjadi:

1) Literatur primer

Bentuk dokumen yang memuat karangan yang lengkap dan asli. Jenisnya berbentuk makalah, koleksi karya ilmiah, buku pedoman, buku teks, publikasi resmi, berkala, dan lain-lain.

2) Literatur sekunder

Biasa disebut sarana dalam penemuan informasi pada literatur 
primer. Jenisnya berbentuk indeks, bibliografi, abstrak, tinjauan literatur, katalog induk, dan lainlain.

\section{Perilaku Pencarian Informasi}

Pencarian informasi merupakan bagian dari kehidupan sehari-hari. Wilson (dalam Yusup, 2010, hlm. 104105), memberikan penjelasan bahwa pencarian informasi bertujuan untuk mencari informasi yang dibutuhkan. Dalam pencarian informasi, individu akan berinteraksi atau menggunakan sistem pencarian manual melalui media tekstual seperti buku, koran, majalah, ilmiah dan perpustakaan, atau juga dapat menggunaka media yang berbasis komputer seperti internet. Dengan kata lain, perilaku pencarian informasi adalah suatu kegiatan atau aktivitas dari individu dalam mencari informasi yang dibutuhkan atau diinginkan dengan suatu tujuan tertentu.

Peneliti akan menggunakan model perilaku pencarian informasi yakni yang dikemukakan oleh Ellis. Hal ini, dimaksudkan untuk memudahkan peneliti fokus kepada satu hal saja. Ellis (dalam Yusup, 2010, hlm. 105), mengemukakan beberapa karakteristik perilaku pencarian informasi dari para peneliti, yakni sebagai berikut:

\section{a. Starting}

Starting merupakan kegiatan yang dilakukan individu dengan mulai mencari informasi misalnya bertanya pada seseorang yang ahli di salah satu bidang keilmuan yang dibutuhkan.

\section{b. Chaining}

Chaining merupakan kegiatan yang dilakukan individu dengan menulis hal-hal yang dianggap penting dalam catatan kecil, dengan kata lain menelusur sitasi atau bentuk lain dari materi referensi. Kegiatan chaining sendiri dapat dilakukan dengan dua cara, yakni backward chainingdan forward chaining.

c. Browsing

Browsing merupakan aktivitas mencari informasi yang terstruktur atau semistruktur pada bidang yang diamati.

\section{d. Differentiating}

Differentiating merupakan pembagian atau reduksi data atau pemilihan data mana yang akan digunakan dan mana yang tidak perlu.

\section{e. Monitoring}

Monitoring adalah kegiatan dimana seseorang selalu memantau atau mencari berita-berita atau informasiinformasi yang terbaru (up-to-date) secara teratur dengan memfokuskan pada sumber yang telah dipilih.

\section{f. Extracting}

Extracting adalah kegiatan mengambil salah satu informasi yang berguna dalam sebuah sumber tertentu. Misalnya, mengambil salah 
satu file dari sebuah world wide web (www) dalam dunia internet.

g. Verifying

Verifying merupakan kegiatan memeriksa tingkat keakuratan informasi yang dipilihnya. Jadi, kegiatan ini terdiri dari penilaian dan pengecekan kesesuaian dan ketepatan suatu informasi yang telah didapatkan. Kegiatan ini dapat dilakukan dengan cara pengecekan ulang terhadap data yang dimiliki, dan melakukan evaluasi, yakni penilaian terhadap hasil yang telah didapat.

\section{h. Ending}

Ending merupakan akhir dari pencarian informasi yang biasanya bersamaan dengan berakhirnya suatu tugas atau penelitian. Setelah informasi selesai diolah, individu dapat menyajikan informasi itu sesuai tujuannya. Misalnya, dalam bentuk makalah, artikel, skripsi, dan sebagainya.

Kegiatan pencarian informasi yang diungkapkan Ellis ini tidak selalu harus dilakukan satu persatu secara berurutan. Adakalanya beberapa tahapan dilakukan secara sekaligus seperti ketika melakukan tahap chaining juga melakukan tahap browsing dan monitoring. Jadi, model ini pada dasarnya adalah fitur yang dilalui seseorang dalam pencarian informasi.

\section{Hambatan Pencarian Informasi}

Dalam melakukan proses pencarian informasi, tidak selamanya berjalan dengan mulus dan lancar. Terkadang ada hambatan-hambatan yang harus dihadapi. Wilson (dalam Winarsih, 2013, hlm.23), dalam teori pencarian informasinya menyebutkan bahwa hambatan atau rintangan dalam pencarian informasi berasal dari diri pribadi, interpersonal, dan lingkungan. Dapat dikatakan bahwa hambatan berasal dari faktor internal dan eksternal. Faktor internal adalah faktor penghambat yang berasal dari dalam diri seseorang atau pencari informasi. Faktor ini dapat ditemukan dari sifat seseorang, psikologis, pendidikan, status sosial, ekonomi, budaya, dan sebagainya, ketidakmampuan memanfaatkan fasilitas. Sedangkan faktor eksternal merupakan faktor penghambat yang berasal dari luar diri seseorang. Contohnya adalah waktu, kesulitan akses, media, sarana dan fasilitas yang tidak memadai, situasi ekonomi, keterbatasan koleksi, dan sebagainya.

\section{Metode}

Penelitian ini menggunakan pendekatan kualitatif deskriptif yang dilakukan untuk mengetahui gambaran perilaku pencarian informasi mahasiswa Departemen Pendidikan Bahasa Asing Universitas Pendidikan Indonesia (DPBA UPI). Penelitian ini didesain dengan menggunakan model studi kasus. Hal ini dikarenakan dengan menggunakan model 
tersebut dapat diteliti setiap aspek secara mendalam.

Sampel dalam penelitian ini adalah berupa dua belas informan. Informan ini lah yang akan memberikan informasi terkait topik yang diteliti. Pada penelitian ini, informan dipilih dengan menggunakan teknik purposive sampling yang berarti pengambilan sumber data dengan pertimbangan tertentu. Subjek dalam penelitian ini terdiri dari mahasiswa DPBA UPI. Fakultas Pendidikan Bahasa dan Sastra (FPBS) UPI secara keseluruhan membina delapan departemen. Penelitian ini mengambil enam departemen, yakni Departemen Pendidikan Bahasa Arab, Departemen Pendidikan Bahasa Jepang, Departemen Pendidikan Bahasa Jerman, Departemen Pendidikan Bahasa Perancis, Departemen Pendidikan Bahasa Korea, dan Departemen Pendidikan Bahasa Inggris. Informan yang dipilih dalam penelitian ini diambil dari keseluruhan mahasiswa DPBA UPI yang berjumlah 2209 orang.

Teknik pengumpulan data dalam penelitian ini adalah melalui wawancara dan studi dokumentasi yang menggunakan pedoman wawancara dan pedoman studi dokumentasi. Teknik analisis data dilakukan dengan reduksi d a t a, display d a t a, d a n kesimpulan/verifikasi data.

Tahapan atau prosedur penelitian yang digunakan pada penelitian ini adalah sebagai berikut. a. Identifikasi masalah

b. Mengakrabisasi informan

c. Menentukan subjek penelitian

d. Melakukan kajian pustaka

e. Mengembangkan instrumen penelitian

f. Mengumpulkan data

g. Menganalisis data

h. Memeriksa keabsahan data

i. Mendeskripsikan dan membahas hasil penelitian

j. Menarik kesimpulan

k. Melakukan pelaporan hasil penelitian.

\section{HASIL DAN PEMBAHASAN}

Setelah melakukan pengolahan dan analisis data maka didapatkan hasil penelitian. Dalam penelitian ini, pemaparan bagian ini dilakukan dengan berfokus pada empat hal, yakni kebutuhan informasi DPBA, sumber informasi DPBA, perilaku pencarian informasi DPBA, dan hambatan pencarian informasi.

\section{a. Kebutuhan Informasi mahasiswa DPBA}

Kebutuhan informasi yang seringkali dibutuhkan mahasiswa DPBA UPI adalah kamus dan buku penunjang aktivitas perkuliahan berupa buku teks dan modul. Kemudian, informasi lainnya yang dibutuhkan mahasiswa namun sulit untuk ditemukan adalah literatur yang berkaitan dengan kebudayaan, kesusastraan, novel, tata bahasa, dan informasi dari luar. Sedangkan, bentuk informasi yang digunakan mahasiswa adalah literatur tercetak dan digital. 
Namun, sebagian besar mahasiswa lebih menyukai penggunaan literatur tercetak. Kemudian, mereka juga lebih membutuhkan literatur berbahasa Indonesia dibandingkan dalam bahasa asing walaupun kenyataannya sulit menemukan literatur tersebut sehingga mahasiswa menggunakan literatur yang ada, yakni yang keseluruhannya berbahasa asing.

\section{b. Sumber Informasi mahasiswa DPBA}

Sumber informasi yang digunakan mahasiswa DPBA beraneka ragam namun secara umum didapatkan dari ruang baca departemen yakni berupa koleksi-koleksi buku dan CD yang ada didalamnya. Kemudian teman, kakak tingkat, orang yang dianggap ahli, dosen, internet, dan lembaga di luar UPI. Perpustakaan UPI hanya digunakan untuk mencari kebutuhan informasi dari mata kuliah MKDU, sedangkan untuk mata kuliah yang menjurus ke bahasa asing sendiri, cenderung menggunakan ruang baca.

Jadi, perpustakaan atau ruang baca, buku, dan internet sendiri merupakan sumber informasi yang seringkali digunakan dalam satu waktu dan saling menyempurnakan. Ketika mahasiswa mencari informasi dari buku yang ada di perpustakaan atau ruang baca, kemudian mahasiswa juga melakukan browsing di internet guna melengkapi data yang kurang dari buku dan demikian pula sebaliknya. Kemudian, dilanjutkan atau dimulai dengan mencari informasi ke teman, kakak tingkat, dosen, dan orang yang dianggap mampu memberikan rekomendasi untuk memenuhi kebutuhan mahasiswa.

\section{c. Perilaku Pencarian Informasi mahasiswa DPBA}

Tujuan mahasiswa DPBA mencari informasi adalah untuk mendukung aktivitas perkuliahannya, yakni memenuhi kebutuhan informasi akan tugas dan skripsi untuk mahasiswa tingkat akhir. Perilaku pencarian informasi mahasiswa DPBA sesuai dengan model Ellis, yakni terdiri dari delapan tahapan starting, chaining, browsing, differentiating, extracting, verifying dan ending. Sementara tahapan monitoring tidak dapat terpenuhi karena hanya sebagian kecil mahasiswa yang melakukannya.

Proses starting dilakukan oleh mahasiswa DPBA dengan memulai pencarian informasi dengan menentukan topik kemudian bertanya kepada orang yang dianggapnya dapat memberikan rekomendasi atau solusi seperti teman dan dosen. Topik ini merupakan gambaran mengenai informasi yang akan dilakukan selanjutnya.

Proses chaining dilakukan oleh mahasiswa DPBA melalui bantuan dosen, yakni pemberian rujukan buku yang dapat dipakai. Pencarian informasi ini juga dimulai dengan mengetahui judul dan pengarang dari buku yang direkomendasikan maupun lewat daftar 
pustaka. Informan melakukan proses chaining dengan backward chaining dan forward chaining. Namun, jika disimpulkan sebagian besar informan melakukan proses forward chaining, yakni kegiatan yang dilakukan dengan cara mencari rujukan berdasarkan judul buku atau nama pengarang dari rujukan inti yang telah ada dengan mengaitkan kedepan. Kemudian, jika mencari informasi dari teman atau kaka tingkat, mahasiswa cenderung mencatat informasi yang penting.

Proses browsing dilakukan oleh mahasiswa DPBA melalui sumber informasi perpustakaan dan ruang baca, internet, manusia, dan mencari cara lain seperti datang ke lembaga tertentu dan pergi toko buku. Untuk sumber perpustakaan, ruang baca, atau lembaga dapat menggunakan alat penelusuran ataupun langsung menelusuri rak buku. Kemudian untuk pencarian informasi dari internet dengan cara memasukkan kata kunci dan menelusur web, serta menggali informasi dari sumber manusia. Kemudian, alternatif terakhir adalah dengan datang ke toko buku.

Proses differentiating dilakukan oleh mahasiswa DPBA. Informasi yang didapatkan kemudian dikumpulkan, dibaca, dan disaring mana yang relevan dan tidak relevan dengan kebutuhan. Informasi yang relevan dapat dimanfaatkan dan untuk informasi yang tidak relevan, dapat langsung diabaikan dan tidak digunakan.

Proses extracting dilakukan dengan cara menyalin atau download file dan disimpan jika mendapat informasi dari internet dan jika, menggunakan sumber informasi dari teman, kakak tingkat, atau orang yang dianggap ahli dengan mencatat dan menyimpan catatannya. Kemudian, dengan cara lain yang dapat dilakukan adalah mengambil foto buku yang digunakannya. Penyimpanan data dari sumber informasi ini dilakukan untuk mengantisipasi kebutuhan mendatang jika suatu saat diperlukan.

Mahasiswa DPBA melakukan tahapan ending, yakni dengan mengetahui kapan seharusnya pencarian informasi berakhir dan menyajikan informasi sesuai dengan tugas dan kebutuhan yang dimiliki. Misalnya, dengan menyajikan lewat artikel, ppt, makalah, skripsi, dan sebagainya.

\section{d. Hambatan Pencarian Informasi}

Ada beberapa hambatan yang secara umum dialami mahasiswa DPBA UPI ini, yakni hambatan yang berasal dari dalam diri individu (internal) dan dari luar individu (eksternal).

a. Internal:

1) Keterbatasan bahasa yang dimiliki individu dalam arti lain tidak menguasai bahasa asing dan lebih banyak yang membutuhkan sumber informasi dalam bahasa Indonesia untuk menunjang kebutuhan akademiknya serta 
tidak terlalu lancar dan menguasai bahasa departemen yang diambilnya.

2) Individu tidak memiliki koneksi yang banyak untuk mencari sumber informasi yang tepat.

3) Individu kesulitan memilih informasi yang telah diperoleh karena seringkali infomasi yang ditemukan terlalu banyak sehingga membuat kebingungan.

4) Individu kesulitan memakai OPAC (Online Public Access Catalogue) yang ada di Perpustakaan UPI.

5) Rasa malas yang ada dalam diri individu membuat pencarian informasi dilakukan diwaktu yang singkat dan cenderung mencari sumber informasi yang cepat sehingga pencarian informasi menjadi kurang optimal.

6) Individu tidak menguasai strategi dalam pencarian informasi dengan menggunakan operator boolean, phrase atau exact, dan truncation atau will card.

b. Eksternal:

1) Waktu yang dimiliki individu terbatas sehingga seringkali pencarian informasi tidak optimal dan menggunakan sumber informasi yang cenderung lebih cepat.

2) Banyaknya informasi yang tersedia di internet sehingga menyebabkan individu kebingungan dalam menyaring dan menggunakan informasi yang akurat, berkualitas, dan sesuai kebutuhan.

3) Terbatasnya akses sumber informasi digital yang memuat keseluruhan isi buku sehingga individu harus membayar untuk download atau diharuskan untuk mencari fisik buku.

4) Seringkali tugas yang diberikan dosen sulit dipahami sehingga pencarian informasi menjadi terhambat dan tidak sesuai dengan apa yang diinstruksikan dosen.

5) Perpustakaan UPI tidak mempunyai banyak literatur yang mendukung perkuliahan.

6) Koleksi yang ada di ruang baca departemen kadang kala tidak lengkap sehingga mengharuskan mahasiswa mencari sumber lain.

7) Jarak yang harus ditempuh dan biaya diperlukan jika individu diharuskan untuk mendatangi tempat yang menyediakan sumber informasi terutama di luar UPI.

8) Ada departemen yang tidak setiap saat buka sehingga mahasiswa harus menghubungi mahasiswa yang memegang kunci ruang baca departemen.

9) Terdapat departemen yang tidak memiliki ruang baca. 
Untuk strategi pencarian informasi yang dilakukan mahasiswa DPBA adalah menggunakan strategi yang dapat dilakukan sebelum browsing informasi seperti menentukan kata kunci dan memahami dengan jelas informasi apa yang dibutuhkannya. Kemudian yang kedua adalah ketika melakukan proses pencarian informasi, yakni menggunakan alat bantu pencarian, menggunakan internet, dan sumber informasi lain yang sekiranya dapat mendukung aktivitas perkuliahan.

Dari pemaparan yang telah diuraikan sebelumnya maka dapat disimpulkan bahwa model pencarian informasi yang disampaikan David Ellis sudah sesuai dengan perilaku pencarian yang ditunjukkan mahasiswa. Namun, ada tahapan yang tidak semua mahasiswa melakukannya, yakni tahapan monitoring atau pemantauan informasi. Dengan berdasarkan pada model tersebut dan kenyataan yang terjadi di lapangan, peneliti akan mencoba untuk membuat pola pencarian informasi dalam bentuk bagan. Secara umum pola pencarian informasi yang dilakukan mahasiswa adalah sebagai berikut:

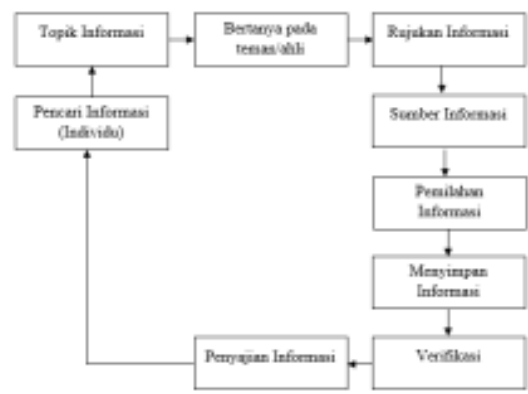

Gambar 1. Pola Pencarian Informasi Mahasiswa DPBA UPI
Pola pencarian informasi diatas merupakan gambaran pencarian informasi mahasiswa yang terjadi di lapangan berdasarkan hasil penelitian dengan melakukan wawancara mendalam kepada mahasiswa DPBA UPI oleh peneliti. Pola ini merupakan hasil analisis lebih lanjut dari model pencarian informasi yang disampaikan David Ellis sehingga dalam penggambarannya tidak jauh berbeda dengan aktivitas yang dilakukan pada model tersebut. Dari bagan di atas dapat disimpulkan bahwa pencari informasi yang dalam hal ini mahasiswa melakukan kegiatan atau aktivitas tertentu dalam mencari informasi, yakni terdiri dalam beberapa tahapan sebagai berikut.

\section{a. Menentukan Topik Informasi}

Pada tahapan ini, individu perlu menentukan topik sebelum mencari informasi lebih dalam. Penentuan terhadap topik informasi ini disesuaikan dengan kebutuhan yang dimiliki individu. Topik sendiri merupakan gambaran secara umum mengenai pencarian informasi yang akan dilakukan sehingga pada tahapan ini individu diharuskan untuk memahami informasi apa yang harus dicari. Selain pemahaman terhadap informasi apa yang harus dicari, aktivitas opsional yang dapat dilakukan individu adalah menentukan format atau bentuk informasi apa yang ingin dicari dan bahasa dalam literatur apa yang dibutuhkan. 


\section{b. Bertanya kepada Teman/Orang yang Dianggap Ahli}

Setelah penentuan topik, individu melakukan proses komunikasi yakni bertanya kepada teman atau orang yang dianggap ahli dan dapat memberikan solusi terhadap kebutuhan informasinya. Tahapan ini dilakukan agar tidak terjadi kesalahpahaman terhadap informasi yang dicari. Aktivitas ini bisa dilakukan dengan menanyakan lebih lanjut hal-hal yang dirasa kurang mengerti atau menimbulkan banyak praduga untuk mempertegas informasi apa yang dibutuhkan sehingga dapat diketahui bagaimana cara memperoleh informasi informasi tersebut. Cara yang lazim digunakan adalah bertanya dan bertukar pendapat dengan rekan sejawat, kakak tingkat, dan dosen. Sewajarnya, pada tahap ini, seseorang akan mendapatkan informasi lebih lanjut dan berguna yang selanjutnya akan membimbingnya kepada sumbersumber informasi.

\section{c. Mendapatkan Rujukan Informasi}

Setelah melakukan proses komunikasi dengan teman atau orang yang dianggap ahli, maka individu akan mendapatkan rujukan terhadap informasi yang dibutuhkannya. Rujukan ini merupakan jalan bagi pencari informasi untuk menemukan sumber informasi. Misalnya, dalam bentuk rekomendasi untuk pencarian informasi di tempat atau sumber tertentu.

\section{d. Penggalian terhadap Sumber} Informasi

Setelah mendapatkan rujukan informasi yang dibutuhkan, maka individu akan mencari informasi dari sumber informasi yang dianggap mampu memenuhi kebutuhannya. Aktivitas ini dapat dilakukan dengan menggali informasi yang berasal dari buku di perpustakaan dan ruang baca, internet, jurnal, sumber manusia, dan sebagainya sampai informasi yang dibutuhkan dapat terpenuhi. Pada sumber informasi di perpustakaan yang sudah terotomasi, maka individu akan menggunakan OPAC sebagai alat bantu telusur baru kemudian menelusur rak koleksi. Di sisi lain, pemustaka dapat juga langsung menelusur tanpa bantuan alat. Kemudian, pada ruang baca, individu biasanya langsung menelusur di rak dikarenakan koleksi yang ada tidak terlalu banyak. Selanjutnya, pada sumber manusia dapat dilakukan dengan menyiapkan catatan untuk menuliskan hal-hal yang dianggap penting.

\section{e. Melakukan Pemilahan Informasi}

Setelah melakukan pencarian pada sumber informasi, hal selanjutnya yang dapat dilakukan individu adalah 
dengan menyaring, memisahkan atau memilih data yang relevan dan tidak relevan dengan kebutuhan. Kegiatan ini ditandai dengan membaca informasi, pengumpulan informasi, dan memilih informasi yang dibutuhkan. Informasi yang relevan dapat digunakan untuk kemudian dapat diolah dan informasi yang tidak relevan dapat diabaikan.

\section{f. Menyimpan Informasi}

Setelah melakukan pemilahan terhadap informasi yang dibutuhkan, individu dapat menggunakan dan menyimpan data-data tersebut baik sebagian maupun keseluruhan data. Aktivitas ini dapat dilakukan dengan cara menyalin atau mengunduh file dari internet, menyimpan catatan dari sumber informasi, mengambil gambar dari literatur yang digunakan, dan sebagainya. Informasi ini disimpan untuk kepentingan proses pembelajaran dan kebutuhan di masa mendatang.

\section{g. Melakukan Verifikasi Informasi}

Setelah menyimpan informasi yang berguna dari sumber informasi, maka individu melakukan proses verifikasi atau pemeriksaan terhadap keakuratan informasi yang telah didapatkan. Proses verifikasi ini dapat dilakukan dengan mengecek ulang informasi yang telah didapatkan dan mengevaluasi kegiatan pencarian informasi dengan cara mengecek kredibilitas pengarang, kesesuaian informasi yang dibutuhkan dengan yang didapatkan, dan kemutakhiran atau mencari informasi yang terbaru.

\section{h. Melakukan Penyajian Informasi}

Setelah semua informasi didapatkan, maka individu dapat melakukan tahapan terakhir dalam aktivitas perilaku pencarian informasi, yakni menyajikan informasi. Penyajian informasi ini disesuaikan ke dalam bentuk atau format yang dibutuhkan oleh individu seperti pada artikel, jurnal, slide presentasi, makalah, skripsi, dan sebagainya. Kemudian, hasil penyajian informasi tersebut diserahkan kepada pihak terkait.

\section{SIMPULAN}

Kebutuhan informasi yang seringkali dibutuhkan mahasiswa DPBA UPI adalah kamus dan buku penunjang aktivitas perkuliahan berupa buku teks dan modul. Sumber informasi yang digunakan mahasiswa DPBA beraneka ragam namun, secara umum didapatkan dari ruang baca departemen, yakni berupa koleksi-koleksi buku dan CD yang ada didalamnya. Kemudian teman, kaka tingkat, orang yang dianggap ahli, dosen, internet, dan lembaga di luar UPI.

Perilaku pencarian informasi yang dilakukan mahasiswa adalah sesuai dengan delapan tahapan yang 
dikemukakan Ellis, yakni terdiri dari delapan tahapan starting, chaining, browsing, differentiating, monitoring, extracting, verifying, dan ending. Secara umum, hambatan yang dialami mahasiswa tidak jauh berbeda, yakni karena rasa malas didalam diri sehingga tugas menjadi tertunda, sulitnya mencari literatur yang mendukung aktivitas perkuliahan di perpustakaan, keterbatasan bahasa, salah paham dengan dosen soal tugas yang dikerjakannya, waktu yang mepet dengan waktu dikumpulkannya tugas, kebingungan memilih data karena terlalu banyaknya dan sedikitnya informasi di internet, aksesibilitas data di internet yang terbatas.

Jadi, berdasarkan pada model David Ellis dan kenyataan di lapangan, dapat disimpulkan bahwa mahasiswa menghasilkan pola yang khas dalam pencarian informasi, yakni terdiri dari delapan tahapan dimulai dengan menentukan topik, bertanya kepada teman atau orang yang dianggap ahli, mendapatkan atau memperoleh rujukan informasi, penggalian terhadap sumber informasi, melakukan pemilahan informasi, menyimpan informasi, melakukan verifikasi informasi, dan melakukan penyajian data.

\section{DAFTAR PUSTAKA}

Darmono. (2001). Kebutuhan dan perilaku pencarian informasi penunjang studi mahasiswa pascasarjana. FKP2T . 1-2(1), hlm. 7-27.

Rozinah, S. (2012). Perilaku pencarian informasi mahasiswa dalam penulisan skripsi (studi kasus di Sekolah Tinggi Agama Islam Nahdlatul Ulama (STAINU) Jakarta). (Tesis). Universitas Indonesia, Jakarta. Tersedia pada http://lontar.ui.ac.id/file?file=digita $1 / 20314244$ - T30901 Perilaku\%20pencarian.pdf. Diakses pada 20 Agustus 2016.

Suwanto, S.A. (1997). Kebutuhan dan perilaku pencarian informasi dosen fakultas kedokteran Undip dan Unissula semarang. (Tesis). Sekolah Pascasarjana, Universitas Indonesia, Bandung. Tersedia dalam.http://eprints.undip.ac.id/19 618/1/sriati-tesis.pdf.Diakses pada 1 September 2016.

Wilson, T.D. (1999) Models in Information behavior research.The Journal of Documentation, 55 (3), hlm. 249- 270.Tersedia pada http://informationR.net/tdw/publ/p apers/1999jdoc.html. Diakses pada 9 Agustus 2016.

Winarsih. (2013). Kebutuhan dan perilaku pencarian informasi taruna angkatan 46 di perpustakaan 
politeknik ilmu pelayaran.

(Skripsi). Universitas Diponegoro, Yogyakarta. Tersedia pada.http://eprints.undip.ac.id/407 40/1/Skripsi_Winarsih_A2D00907 3.pdf. Diakses pada 1 Februari 2016.

Yusup, P.M., Subekti, P. (2010). Teori dan praktik penelusuran informasi:information retrival. Bandung: Kencana Pranata Media Grup. 